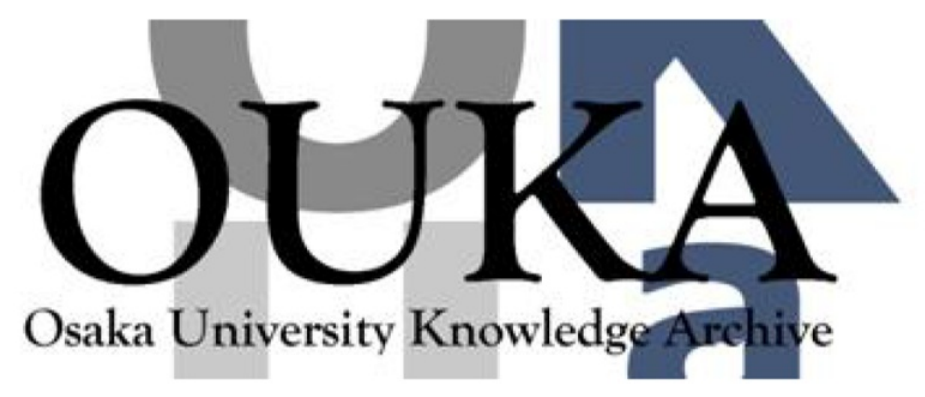

\begin{tabular}{|c|l|}
\hline Title & $\begin{array}{l}\text { A New Method of Generation of Bismuthonium } \\
\text { Ylides and the ir Efficient Trapping with } \\
\text { Sulphenes }\end{array}$ \\
\hline Author(s) & $\begin{array}{l}\text { Ogawa, Takuji; Murafuji, Toshihiro; Suzuki, } \\
\text { Hitomi }\end{array}$ \\
\hline Citation & $\begin{array}{l}\text { JOURNAL OF THE CHEMICAL SOCIETY-CHEMICAL } \\
\text { COMMUNICATIONS. 22 p. 1749-p. 1751 }\end{array}$ \\
\hline Issue Date & $1989-11-15$ \\
\hline oaire:version & VoR \\
\hline URL & https://hdl.handle. net/11094/3280 \\
\hline rights & \\
\hline Note & \\
\hline
\end{tabular}

Osaka University Knowledge Archive : OUKA

https://ir. Library. osaka-u. ac. jp/

Osaka University 


\title{
A New Method of Generation of Bismuthonium Ylides and their Efficient Trapping with Sulphenes
}

\author{
Takuji Ogawa,* Toshihiro Murafuji, and Hitomi Suzuki* \\ Department of Chemistry, Faculty of Science, Ehime University, Matsuyama 790, Japan
}

Bismuthonium ylides are generated by reacting triphenylbismuth oxide or dichloride with sodium salts of cyclic and open chain 1,3-dicarbonyl compounds; ylides from open chain 1,3-dicarbonyl compounds, which readily decompose on standing to produce $C$-phenylation products, can be efficiently trapped by sulphenes to afford 1,3-oxathiole-3,3-dioxides in good yields.

Only two methods have so far been reported for the preparation of bismuthonium ylides. Lloyd and co-workers prepared several types of bismuthonium ylides by heating diazo-compounds with triphenylbismuthine in the presence of a copper catalyst. ${ }^{1}$ Barton and co-workers obtained a stable bismuthonium ylide by the reaction of triphenylbismuth carbonate with dimedone. ${ }^{2}$ Both methods lack generality for the preparation of wider types of bismuthonium ylides. The high temperature conditions employed in the former operation were incompatible with unstable bismuthonium ylides. The latter procedure was found to be applicable only for very limited types of cyclic 1,3-dicarbonyl compounds such as dimedone and Meldrum's acid;2,3 with open chain 1,3-dicarbonyl compounds it always led to $C$ - or $O$-arylated products. In the course of our studies on some stabilized bismuthonium ylides, ${ }^{3.4}$ it became necessary to develop a methodology which was applicable for the preparation of less stabilized bismuthonium ylides of more general types. Herein, we report a new method for the generation of bismuthonium ylides; the reaction of triphenylbismuth oxides or dichlorides with sodium salts of 1,3-dicarbonyl compounds gives the corresponding bismuthonium ylides (1) in moderate to good yields. Unstable bismuthonium ylides derived from straight chain 1,3-dicarbonyl compounds could be efficiently trapped by sulphenes to give 1,3-oxathiole-3,3-dioxide derivatives (2).

A typical example of the preparation of a stabilized bismuthonium ylide is as follows: to a suspension of the sodium salt of 1,3-dione in tetrahydrofuran (THF) $\left(2 \mathrm{~cm}^{3}\right)$ generated from sodium hydride (ca. $80 \mathrm{mg}$ ) and 5,5-

Table 1. Reaction of stable bismuthonium ylides with sulphenes.<smiles></smiles><smiles></smiles><smiles>[R]C(=O)C1=C([R])OC([R3])S1</smiles><smiles>[R]</smiles>
$\mathrm{R}^{3}$ $\mathrm{CH}_{2} \mathrm{CMe}_{2} \mathrm{CH}_{2}$ $\mathrm{H}$

Yield/\%
73
67
64
65
69
23

$$
\begin{gathered}
\text { M.p. } /{ }^{\circ} \mathrm{C} \\
188-189 \\
135-138 \\
63-67 \\
59-62 \\
236-240 \\
184-187
\end{gathered}
$$

$\mathrm{CH}_{2}-\mathrm{CH}_{2}{ }^{\mathrm{b}}$

a Pale yellow crystals, m.p. $131-135^{\circ} \mathrm{C}$ (from $\mathrm{CH}_{2} \mathrm{Cl}_{2}$-hexane), made from $\mathrm{Ph}_{3} \mathrm{BiCl}_{2}$ and cyclohexane-1,3-dione, ${ }^{1} \mathrm{H} \mathrm{NMR}\left(\mathrm{CDCl}_{3}\right)$ $1.90-2.30(\mathrm{~m}, 2 \mathrm{H}), 2.41-2.70(\mathrm{t}, 4 \mathrm{H}), 7.40-7.90(\mathrm{~m}, 15 \mathrm{H})$. ${ }^{\mathrm{b}}$ Pale yellow crystals, m.p. $128-132^{\circ} \mathrm{C}$ (from $\mathrm{CH}_{2} \mathrm{Cl}_{2}$-hexane), made from $\mathrm{Ph}_{3} \mathrm{BiCl}_{2}$ and cyclopentane-1,3-dione, ${ }^{1} \mathrm{H} \mathrm{NMR}\left(\mathrm{CDCl}_{3}\right) 2.70(\mathrm{~s}, 4 \mathrm{H})$, $7.38-8.04(\mathrm{~m}, 15 \mathrm{H})$. 


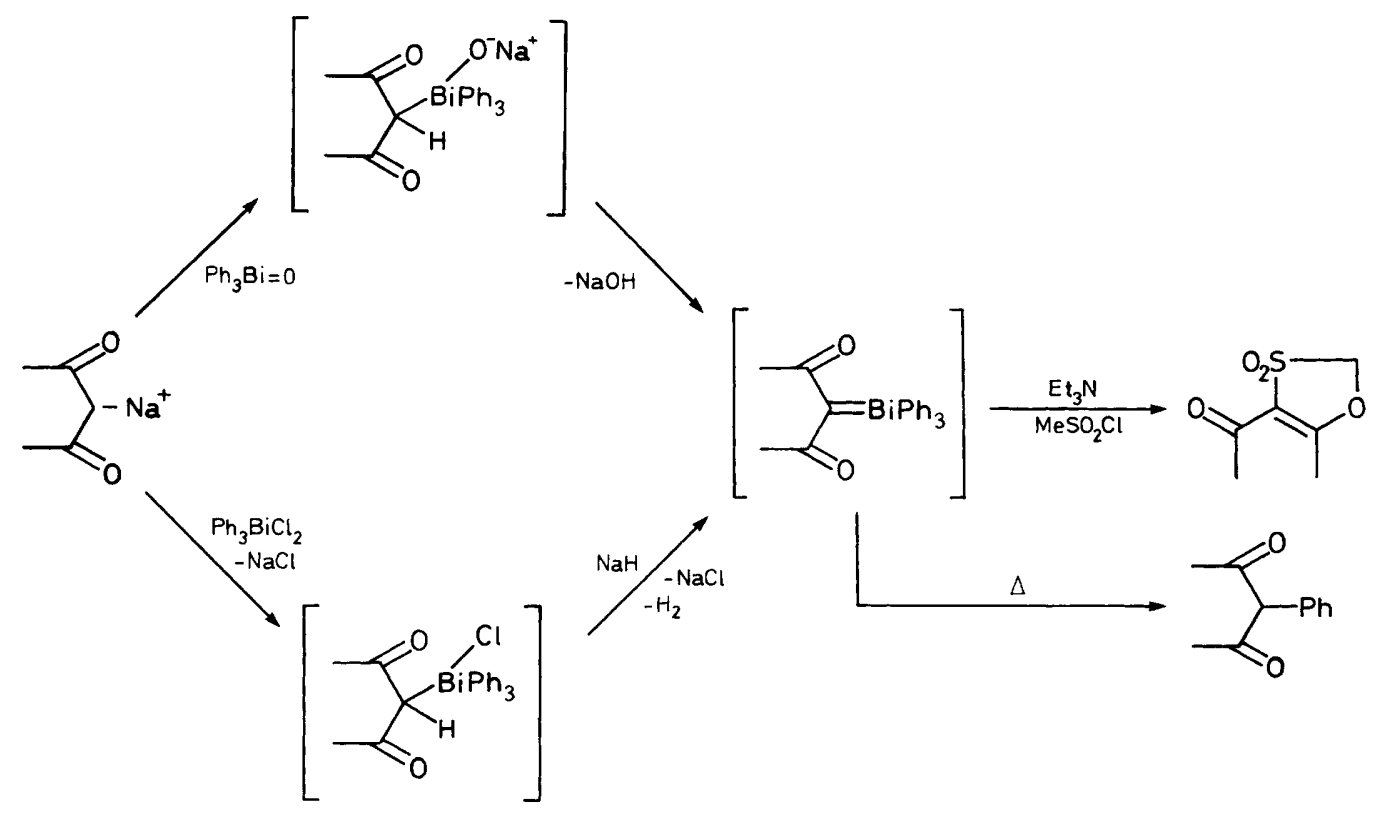

Scheme 1

Table 2. Generation of bismuthonium ylides and their trapping with methylenesulphene.<smiles>[R]C(=O)[C+]C([R15])C([R])=O</smiles><smiles></smiles>

(1)<smiles>[R]C(=O)C1=C([R])OC[Sb]1CC</smiles>

(2)

\begin{tabular}{|c|c|c|c|c|c|c|}
\hline & \multirow[b]{2}{*}{$\mathrm{R}^{1}$} & \multirow[b]{2}{*}{$\mathrm{R}^{2}$} & \multirow[b]{2}{*}{$\mathrm{X}_{2}$} & \multicolumn{2}{|c|}{$\begin{array}{l}\text { Yield } \\
1 \%^{a}\end{array}$} & \multirow{2}{*}{ M.p. $/{ }^{\circ} \mathrm{C}$} \\
\hline & & & & (1) & (2) & \\
\hline b & $\mathrm{CH}_{2} \mathrm{CMe}_{2}$ & $\mathrm{CH}_{2}$ & $\mathrm{Cl}_{2}$ & 52 & & $75^{3}$ \\
\hline c & $\mathrm{Me}$ & $\mathrm{Me}$ & $\mathrm{Cl}_{2}$ & & 65 & $108-111$ \\
\hline d & $\mathrm{Ph}$ & $\mathrm{Me}$ & $\mathrm{Cl}_{2}$ & & 17 & $106-109$ \\
\hline $\mathbf{e}$ & $\mathrm{MeO}$ & $\mathrm{Me}$ & $\mathrm{Cl}_{2}$ & & 39 & $199-202$ \\
\hline f & $\mathrm{CH}_{2} \mathrm{CMe}_{2}$ & $\mathrm{CH}_{2}$ & $=0$ & 84 & & $75^{3}$ \\
\hline g & $\mathrm{Me}$ & $\mathrm{Me}$ & $=\mathrm{O}$ & & 95 & $108-111$ \\
\hline
\end{tabular}

a The yields of bismuthonium ylides (1) refer to isolated compounds.

dimethylcyclohexan-1,3-dione (140 mg, $1.0 \mathrm{mmol})$, was added triphenylbismuth dichloride $(511 \mathrm{mg}, 1.0 \mathrm{mmol})$ at $-20^{\circ} \mathrm{C}$ under nitrogen. The colourless suspension turned yellow and after $c a$. $1 \mathrm{~h}$ a clear solution was obtained. Monitoring by TLC $\left(\mathrm{SiO}_{2}, 1 \% \mathrm{MeOH} / \mathrm{CH}_{2} \mathrm{Cl}_{2}\right)$ showed only one new spot at $R_{\mathrm{f}}$ 0.25 . The product was purified by passing through a short silica-gel column using $1 \% \mathrm{MeOH} / \mathrm{CH}_{2} \mathrm{Cl}_{2}$ as the eluent. The isolated yield of ylide (1b) was $52 \%$, m.p. $75^{\circ} \mathrm{C} .{ }^{2}$

Reaction of the sodium salt of acetylacetone with triphenylbismuth dichloride was also found to form the corresponding bismuthonium ylide as was readily revealed by TLC $\left(R_{\mathrm{f}} 0.25\right)$ and ${ }^{13} \mathrm{C}$ NMR (absorption of the ylide carbon was observed at $\delta 100.80$ in $\left[{ }^{2} \mathrm{H}_{8}\right]$ THF solution) spectroscopic inspection of the crude product mixture. After chromatographic separation, however, no bismuthonium ylide could be detected and only the $C$-phenylated acetylacetone was obtained in $65 \%$ yield. Attempts to trap the supposed ylide with aldehydes or alk-1-ynes in the presence of a copper catalyst failed. Fortunately, we have observed that triphenylbismuthonio4,4-dimethyl-2,6-dioxyocyclohexan-1-ide (1b) reacted very efficiently with sulphenes to give 1,3-oxathiole-3,3-dioxide (2) derivatives in moderate to good yield (Table 1 ). This was also the case for the unstable bismuthonium ylide, derived from acetylacetone, and the corresponding 1,3-oxathiole-3,3-dioxide derivative was isolated in $65 \%$ yield by a typical procedure: to an ice-salt cooled suspension of the sodium salt of 1,3-dione generated from sodium hydride (ca. $80 \mathrm{mg}$ ) and acetylacetone $(100 \mathrm{mg}, 1.0 \mathrm{mmol})$, a THF solution of triphenylbismuth dichloride $(560 \mathrm{mg}, 1.1 \mathrm{mmol})$ was added in one step. The suspension turned to a pale yellow solution after about $5 \mathrm{~min}$, the solution was stirred for an hour to complete the reaction. When triethylamine $(100 \mathrm{mg}, 1.0 \mathrm{mmol})$ and methanesulphonyl chloride (115 $\mathrm{mg}, 1.0 \mathrm{mmol}$ ) were sequentially added dropwise to the solution at $-40^{\circ} \mathrm{C}$, the yellow colour faded, and a colourless solid began to precipitate. When the reaction was over, the precipitate was filtered off and the solvent removed to give a pale brown oil, which was purified by passing through a silica-gel column with $1 \%$ $\mathrm{MeOH} / \mathrm{CH}_{2} \mathrm{Cl}_{2}$ as the eluents. The first fraction contained triphenylbismuth $(260 \mathrm{mg}, 59 \%)$ and the second fraction afforded the 1,3-oxathiole-3,3-dioxide derivative in $65 \%$ yield. Triphenylbismuth oxide similarly reacted with sodium salts of the carbon acids to give the corresponding ylides in better yields (Table 2); reactions were carried out at room temperature. In all cases reaction mixtures were kept until a clear solution was obtained.

The above results clearly establish the initial formation and subsequent transformation of bismuthonium ylide during the reaction of triphenylbismuth dichloride (or oxide) and the sodium salt of acetylacetone.

The present method provides a simple way of generating or preparing bismuthonium ylides from various cyclic and acyclic 1,3-dicarbonyl compounds. Unstable bismuthonium ylides 
from open chain 1,3-dicarbonyl compounds are easily converted into $C$-phenylated products on standing. This finding strongly suggests that the $C$-arylation of 1,3-dicarbonyl compounds with the pentavalent bismuth compounds, reported by Barton and co-workers, ${ }^{2}$ proceeds through the intermediacy of the bismuthonium ylide despite the different mechanistic pathway proposed therein.

Received, 24th June 1989; Com. 9/02679G

\section{References}

1 D. Lloyd and M. I. C. Singer, J. Chem. Soc., Chem. Commun., 1967, 1042; C. Glidewell, D. Lloyd, and S. Metcalfe, Synthesis, $1988,319$.

2 D. H. R. Barton, J. Blazejewski, B. Charpiot, J.-P. Finet, W. B. Motherwell, M. T. B. Papoula, and S. P. Stanforth, J. Chem. Soc., Perkin Trans. 1, 1985, 2667.

3 H. Suzuki, T. Murafuji, and T. Ogawa, Chem. Lett., 1988, 847.

4 T. Ogawa, T. Murafuji, and H. Suzuki, Chem. Lett., 1988, 849; T. Ogawa, T. Murafuji, K. Iwata, and H. Suzuki, ibid., 1989, 325. 